University of Nebraska - Lincoln

DigitalCommons@University of Nebraska - Lincoln

Biological Systems Engineering: Papers and

Publications

Biological Systems Engineering

2011

\title{
Biocomposites developed using water-plasticized wheat gluten as matrix and jute fibers as reinforcement
}

Narendra Reddy

University of Nebraska-Lincoln

Yiqi Yang

University of Nebraska-Lincoln, yyang2@unl.edu

Follow this and additional works at: https://digitalcommons.unl.edu/biosysengfacpub

Part of the Biological Engineering Commons

Reddy, Narendra and Yang, Yiqi, "Biocomposites developed using water-plasticized wheat gluten as matrix and jute fibers as reinforcement" (2011). Biological Systems Engineering: Papers and Publications. 191. https://digitalcommons.unl.edu/biosysengfacpub/191

This Article is brought to you for free and open access by the Biological Systems Engineering at DigitalCommons@University of Nebraska - Lincoln. It has been accepted for inclusion in Biological Systems Engineering: Papers and Publications by an authorized administrator of DigitalCommons@University of Nebraska Lincoln. 


\title{
Biocomposites developed using water-plasticized wheat gluten as matrix and jute fibers as reinforcement
}

\author{
Narendra Reddy ' and Yiqi Yang I, 2,3
}

\author{
I. Department of Textiles, Clothing and Design, 234 HECO Building, University of Nebraska-Lincoln, Lincoln, NE 68583-0802, USA \\ 2. Department of Biological Systems Engineering, 234 HECO Building, University of Nebraska-Lincoln, Lincoln, NE 68583-0802, USA \\ 3. Nebraska Center for Materials and Nanoscience, 234 HECO Building, University of Nebraska-Lincoln, Lincoln, NE 68583-0802, USA \\ Corresponding author — Yiqi Yang, 234 HECO Building, University of Nebraska-Lincoln, Lincoln, NE 68583-0802, USA; yyang2@unl.edu
}

\begin{abstract}
Biocomposites developed from wheat gluten using water without any chemicals as plasticizer and jute fibers as reinforcement have much better flexural and tensile properties than similar polypropylene composites reinforced with jute fibers. Wheat gluten is an inexpensive and abundant co-product derived from renewable resources and is biodegradable but non-thermoplastic. Previous attempts at developing biocomposites from wheat gluten have used plasticizers such as glycerol or chemical modifications to make gluten thermoplastic. However, plasticizers have a considerably negative effect on the mechanical properties of the composites and chemical modifications make wheat gluten less biodegradable, expensive and/or environmentally unfriendly. In the research reported, we developed composites from wheat gluten using water as a plasticizer without any chemicals. Water plasticizes wheat gluten but evaporates during compression molding and therefore does not affect the mechanical properties of the composites. The effect of composite fabrication conditions on the flexural, tensile and acoustic properties was studied in comparison to polypropylene composites reinforced with jute fibers. Wheat gluten composites had flexural strength (20 MPa), tensile strength $(69 \mathrm{MPa})$ and tensile modulus $(7.7 \mathrm{GPa})$ values approximately twice those of polypropylene composites. Water is an effective plasticizer for wheat gluten and could be used to develop various types of inexpensive and biodegradable wheat gluten-based thermoplastics.
\end{abstract}

Keywords: biocomposites, wheat gluten, matrix, plasticizers

\section{Introduction}

Extensive efforts are being made to develop biodegradable and environmentally friendly biocomposites using polymers from renewable resources as the matrix and/or reinforcing materials. ${ }^{1-11}$ Both partially green composites where either the reinforcing or the matrix materials are biodegradable and completely green composites where both the reinforcing and matrix materials are biodegradable and derived from renewable resources have been developed. ${ }^{1-3}$ Natural cellulose fibers such as jute and kenaf, byproducts of food crops such as wheat straw, poultry feathers, proteins and oils from soybeans, starch-based polymers and biodegradable synthetic polymers such as poly(lactic acid) that are derived from annually renewable resources are some examples of materials that have been used to develop biocomposites. ${ }^{1-10}$ In addition, red algae fiber and bacterial cellulose fibers have been recently studied as potential reinforcements for biodegradable composites. ${ }^{12,13}$

Byproducts of grain processing such as distillers' dried grains, wheat gluten and soy proteins are inexpensive and abundant raw materials suitable for various industrial applications. These protein byproducts are inevitably generated during the processing of grains for food or fuel, and therefore do not need additional resources. About 100 million pounds of wheat gluten are produced in the USA every year with a selling price of $\$ 0.50$ to $\$ 0.80$ per pound, lower than those of soy protein and zein and the common synthetic polymers such as polyethylene ( $\$ 0.80$ per pound) and polystyrene ( $\$$ I per pound) that are currently being used for thermoplastic applications. ${ }^{14}$ Soy proteins and soy oil have been chemically modified and extensively studied for composite applications. I, 4, 5 Utilizing these byproducts for composite applications will add value to the byproducts, improve the income from the crops from which they are derived and benefit farmers economically. These agricultural byproducts are derived from renewable resources and therefore products developed from them will be environmentally friendly. Similar to the byproducts generated during grain processing, lignocellulosic byproducts such as corn stover, soy straw and cotton stalks generated during cultivation of the crops have been utilized to obtain natural cellulose fibers for various applications. ${ }^{15-17}$ Biodegradable synthetic polymers such as poly(lactic acid) have also been reinforced with bamboo fibers to develop biocomposites. ${ }^{18}$

Attempts have been made to utilize the byproducts of grain processing, such as soy proteins and wheat gluten, for composite and other industrial applications. Wheat gluten was used as matrix, hydroethyl cellulose as filler and glycerol as plasticizer and compression molded to form thermoplastics. ${ }^{19}$ The effect of molding 
temperature on the properties of wheat gluten plastics was studied. ${ }^{20}$ It was reported that molding temperature affected the properties of the thermoplastic and that heating below $130^{\circ} \mathrm{C}$ introduced disulfide bonds and contributed to the three-dimensional protein networks. ${ }^{20}$ The effect of five plasticizers including water on the functional properties and reactivity of wheat gluten was studied. $^{21}$ It was reported that, at the same molar ratios, water had a similar plasticizing effect as glycerol and I,4-butanediol. ${ }^{21}, 22$ Wheat gluten was modified using urea and sodium hydroxide and used as a binder in particle board. ${ }^{3}$ It was reported that modified wheat gluten could partially substitute urea-formaldehyde resin in particle boards. ${ }^{3}$ Wheat gluten plasticized with glycerol was used as a matrix and hemp and wood fiber were used as reinforcement to develop composites. ${ }^{23}$ It was reported that the addition of natural fibers improved the mechanical properties and water resistance of the composites. Recently, wheat gluten plasticized with glycerol was reinforced with industrial hemp fibers to develop plastics. ${ }^{24}$ It was reported that short hemp fibers were able to reinforce and improve the properties of the wheat gluten plastics. The transport and tensile properties of compressionmolded wheat gluten films was studied by Gällstedt et al. ${ }^{25}$ Wheat gluten was blended with zein and composites were developed at room temperature. ${ }^{26}$ It was reported that the wheat gluten-zein composites had compressive yield strength comparable to that of polypropylene (PP). ${ }^{26}$

Although efforts have been made to develop composites and other thermoplastics using wheat gluten as the binder or matrix material, previous efforts on utilizing wheat gluten for composites applications have chemically modified the wheat gluten or used plasticizers such as glycerol to make the wheat gluten thermoplastic. Chemical modifications make wheat gluten expensive and may not be environmentally friendly, and there are also concerns about the processing and disposal of the products developed from chemically modified wheat glutens. Products developed from wheat gluten using plasticizers have poor mechanical properties and water stability. Plasticizers such as glycerol are hydrophilic and absorb considerable amounts of water that leads to the products having poor properties. For instance, wheat gluten films with $25 \%$ glycerol content absorbed $47.5 \%$ water compared to $73 \%$ for films with $40 \%$ glycerol. ${ }^{25}$ Similarly, the Young's modulus of wheat gluten-based materials decreased to 10.4 MPa from 34.7 $\mathrm{MPa}$ when the glycerol content was increased from 20 to $30 \% .{ }^{23}$ Therefore, it is desirable to avoid the use of chemical modifications or plasticizers to obtain wheat gluten-based products with good properties.

In the research reported here, we used wheat gluten as the matrix in the presence of water as plasticizer and jute fibers as reinforcement to develop composites. The effect of processing conditions such as the amount of wheat gluten and time and temperature of compression molding on the flexural and tensile properties of the composites was studied in comparison to similar PP-jute composites.

\section{Materials and Methods}

\section{Materials}

Commercially available wheat gluten (Wheat Pro 80 ) was supplied by Archer Daniels Midlands Company (Decatur, IL). Jute fibers were purchased from Bast Fibers LLC (Cresskill, NJ). Jute fibers were chosen for the study because jute is relatively inexpensive and more widely available than other common lignocellulosic fi- bers such as flax and hemp. However, the properties of the composites developed are expected to vary depending on the type of reinforcing fibers used. The jute fibers used for this study had an average fineness of 32 denier (denier is defined as the weight of the fibers per $9000 \mathrm{~m}$ and one denier is approximately equivalent to $130 \mathrm{MPa}$ ), tensile strength of $2.4 \mathrm{~g}_{\text {denier }}{ }^{-1}$, breaking elongation of $1.4 \%$ and Young's modulus of $187 \mathrm{~g}$ denier $^{-1}$. PP fibers were supplied by Drake Extrusion (Martinsville, VA). The PP fibers were of I5 denier and $84 \mathrm{~mm}$ long and crimped, with a width of $45 \mathrm{~mm}$, tensile strength of $4.0 \mathrm{~g}$ denier ${ }^{-1}$, melting temperature of $162{ }^{\circ} \mathrm{C}$, melt flow index of $20 \mathrm{~g}(10 \mathrm{~min})^{-1}$ measured at $230{ }^{\circ} \mathrm{C}$, crystallinity of $50 \%$ and density of $0.90 \mathrm{~g} \mathrm{~cm}^{-3}$.

\section{Wheat gluten-jute composites}

The jute fibers were opened by hand and carded twice to open and parallelize the fibers. Mats of jute fibers were removed from the carding machine and cut to rectangular pieces of $25.4 \mathrm{~cm}$ $\times 30.5 \mathrm{~cm}$. The jute fiber mats were weighed to obtain the required amount of fibers depending on the ratio of the jute fibers and wheat gluten used for each composite. The required amount of wheat gluten was weighed and evenly sprayed on the jute fiber mats. Water equivalent to twice the weight of the total jute fibers and wheat gluten used was sprayed onto the jute fibers and wheat gluten. The weight of the pre-preg was determined to ensure that the same weight was used for each composite. The pre-preg was placed between two aluminium foils and compression molded in a composite press (Carver Inc., Wabash, IN) at a predetermined temperature $\left(150-180^{\circ} \mathrm{C}\right)$ and for a particular time (5 to $\left.20 \mathrm{~min}\right)$ at a pressure of approximately I $40 \mathrm{MPa}$. Spacers (3.2 $\mathrm{mm}$ thick) were placed at the edges of the composite press to control the density of the composite at $0.47 \mathrm{~g} \mathrm{~cm}^{-3}$. After compression, the press was cooled using running cold water and the composite formed was removed.

\section{PP-jute composites}

The PP and jute fibers were carded separately. Later, the required ratio of PP/jute fibers was weighed and carded together three times to obtain homogeneous mixing of the fibers. Mats of the fiber blends were removed from the carding machine and cut to pieces of $25.4 \mathrm{~cm} \times 30.5 \mathrm{~cm}$. Several of the fiber mats were stacked to get the required weight/unit area and were later compression molded at $190{ }^{\circ} \mathrm{C}$ for $90 \mathrm{~s}$. The temperature and time required to make the $\mathrm{PP}$-jute composites were optimized in our earlier researches. ${ }^{6-10}$

\section{Optimization of conditions}

The composite fabrication conditions such as the amount of reinforcing and matrix materials and time and temperature of compression molding were optimized. Initially, we optimized the amount of matrix and reinforcing material used in the composite. Later the temperature of processing the composite was optimized, and finally the optimum time of processing was determined.

\section{Thermal analysis}

A DSC instrument (model DSC $822^{\mathrm{e}}$, Mettler Toledo, Columbus, $\mathrm{OH}$ ) was used to study the thermal behavior of wheat gluten without water and with water equivalent to twice the weight of gluten. The samples were placed in sealed pans and heated to 250 ${ }^{\circ} \mathrm{C}$ at a heating rate of $20{ }^{\circ} \mathrm{C} \mathrm{min}$. 


\section{Composite characterization}

The composites were conditioned in a standard testing atmosphere of $21{ }^{\circ} \mathrm{C}$ and $65 \%$ relative humidity for at least $24 \mathrm{~h}$ before testing. Flexural tests were carried out according to ASTM standard D790-03 using an MTS (model Q Test I0, MTS Corporation, Eden Prairie, MN) tensile tester equipped with a $500 \mathrm{~N}$ load cell. The crosshead speed used was $10 \mathrm{~mm} \mathrm{~min}^{-1}$. The peak load was multiplied by 0.1 , offset load by 0.1 and modulus of elasticity (MOE) by 0.01 so that we could include all the flexural data using a common $y$-axis.

Tensile tests were performed using an Instron tensile tester (model 4000, Instron, Norwood, MA) according to ASTM standard D638-03 using dog-bone-shaped specimens. The crosshead speed was $5 \mathrm{~mm} \mathrm{~min}^{-1}$. Six samples from three different composites were tested for the flexural and tensile properties and the average and \pm one standard deviation are reported.

The sound absorption properties of the composites were measured using a small-size Bruel \& Kjaer (Norcross, GA) impedance tube and the absorption coefficients from I to $5 \mathrm{kHz}$ were recorded. Three samples from different composites were tested for the sound absorption and the average readings were used to plot the absorption coefficient curves.

\section{Performance at high relative humidity}

The effect of humidity on the flexural and tensile properties of the composites was tested at two relative humidities (65 and 90\%) at a temperature of $21{ }^{\circ} \mathrm{C}$. Samples were placed in a Caron conditioning chamber (Caron Products and Services Inc., Marietta, $\mathrm{OH}$ ) at the desired temperature and humidity and conditioned for 24 h. After conditioning, the samples were immediately taken out and tested for flexural and tensile properties.

\section{Results and Discussion}

Thermal behavior of wheat gluten with water as plasticizer

The thermal behavior of wheat gluten with and without water as plasticizer is shown in Fig. I.Water acts as an effective plasticizer as shown by the much larger melting peak and melting enthalpy

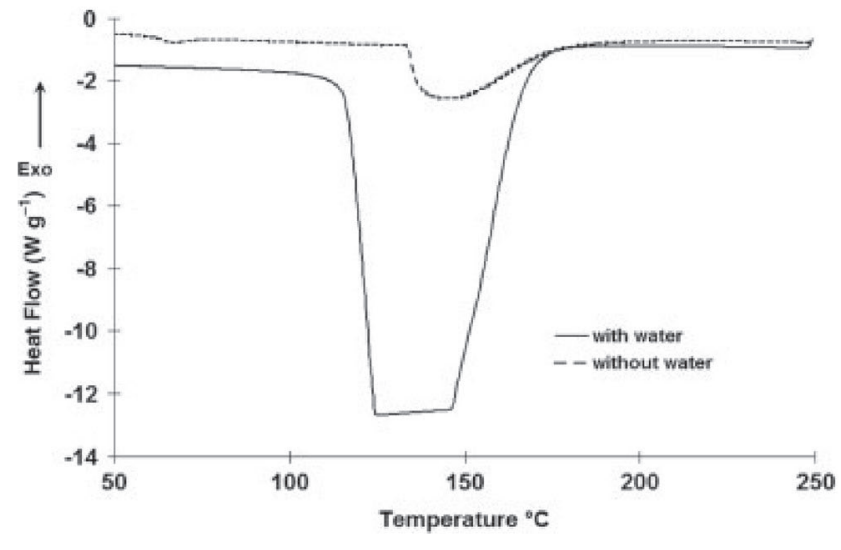

Figure I. DSC thermograms of wheat gluten without and with $200 \%$ water (based on weight of gluten) as the plasticizer. The DSC curves were obtained at a heating rate of $20^{\circ} \mathrm{C} \mathrm{min}^{-1}$.

compared to wheat gluten without plasticizer. The melting enthalpy of wheat gluten without added water is $110 \mathrm{~J} \mathrm{~g}^{-1}$ and that of the wheat gluten with water at twice the weight of gluten as plasticizer was substantially higher at $1.3 \mathrm{~kJ} \mathrm{~g}^{-1}$. However, the DSC curves for the wheat gluten both with and without plasticizer have a melting peak at $150{ }^{\circ} \mathrm{C}$. The melting peak shown by wheat gluten without added water should be due to the presence of up to $10 \%$ moisture in wheat gluten and due to the melting of proteins that have been denatured during the preparation of commercial wheat gluten. ${ }^{27}$

\section{Effect of proportion of wheat gluten on flexural properties} Figure 2 shows the effect of increasing the proportion of wheat gluten on the flexural properties of the composites. Increasing the amount of wheat gluten affects the stiffness and flexural strength but the peak load and offset yield load are relatively unaffected. A wheat gluten concentration of $60 \%$ provides the highest flexural strength and $70 \%$ gives the highest stiffness. At low concentration of wheat gluten, there is insufficient binding material to hold the jute fibers together and therefore the composites have inferior proper-

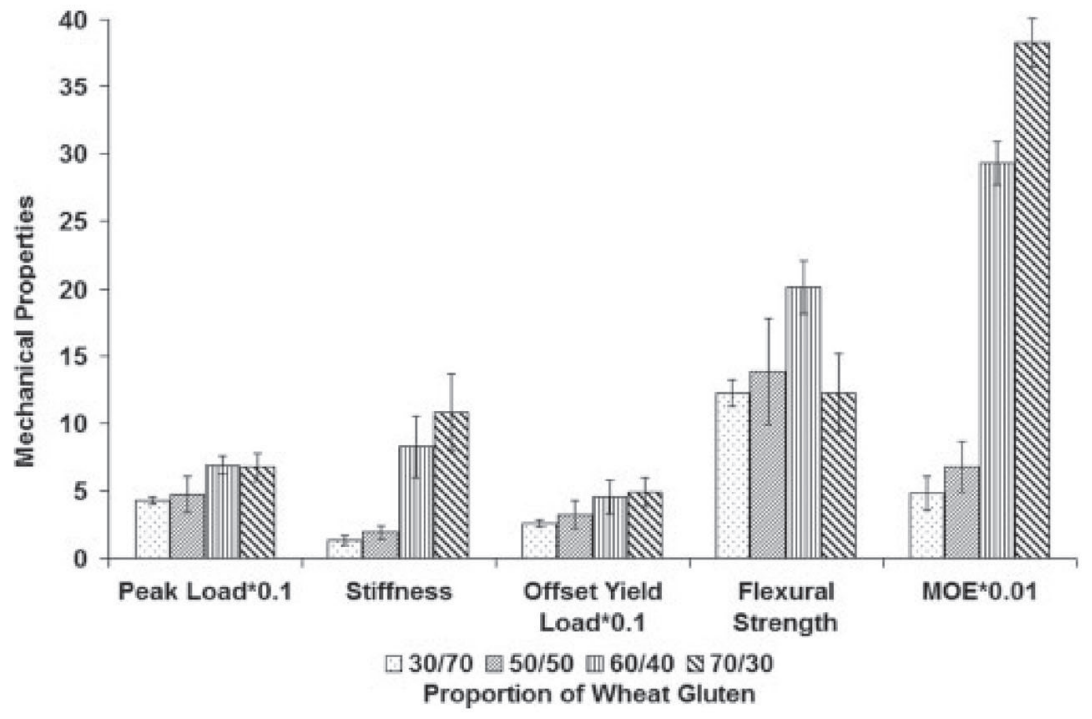

Figure 2. Effect of proportion of wheat gluten on flexural properties of composites. The composites were manufactured by compression molding for $15 \mathrm{~min}$ at a temperature of $170{ }^{\circ} \mathrm{C}$ with a thickness of $3.2 \mathrm{~mm}$ and a density of $0.47 \mathrm{~g} \mathrm{~cm}^{-3}$. 


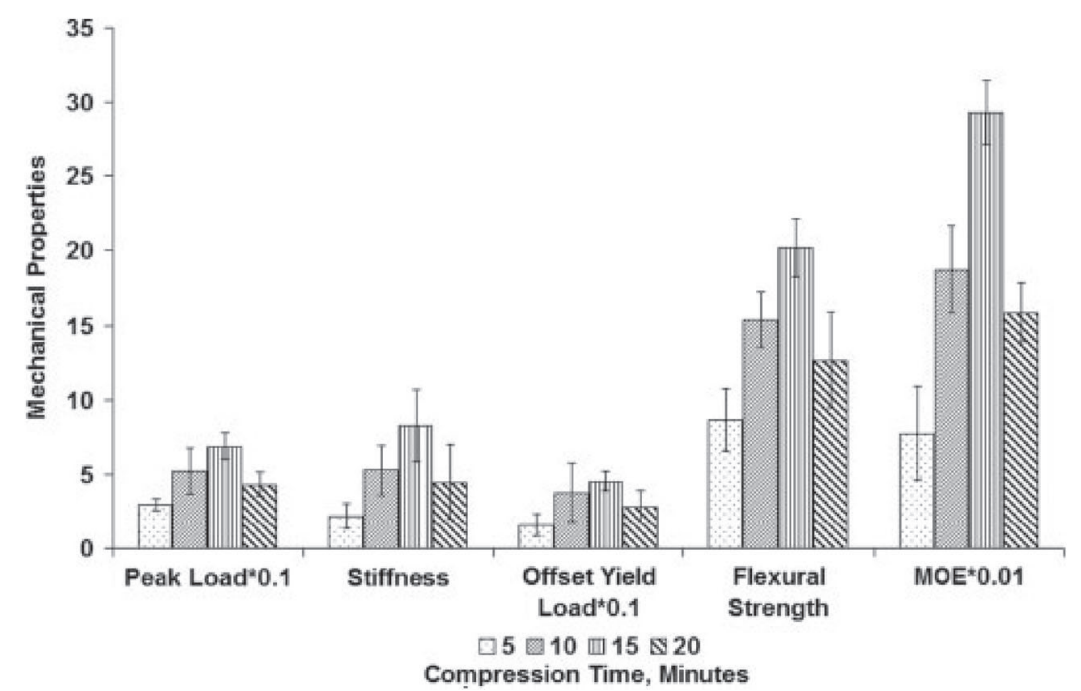

Figure 3. Effect of compression time on flexural properties of wheat gluten-jute composites. The composites were manufactured at a temperature of $170{ }^{\circ} \mathrm{C}$ with a thickness of $3.2 \mathrm{~mm}$ and a density of $0.47 \mathrm{~g} \mathrm{~cm}^{-3}$.

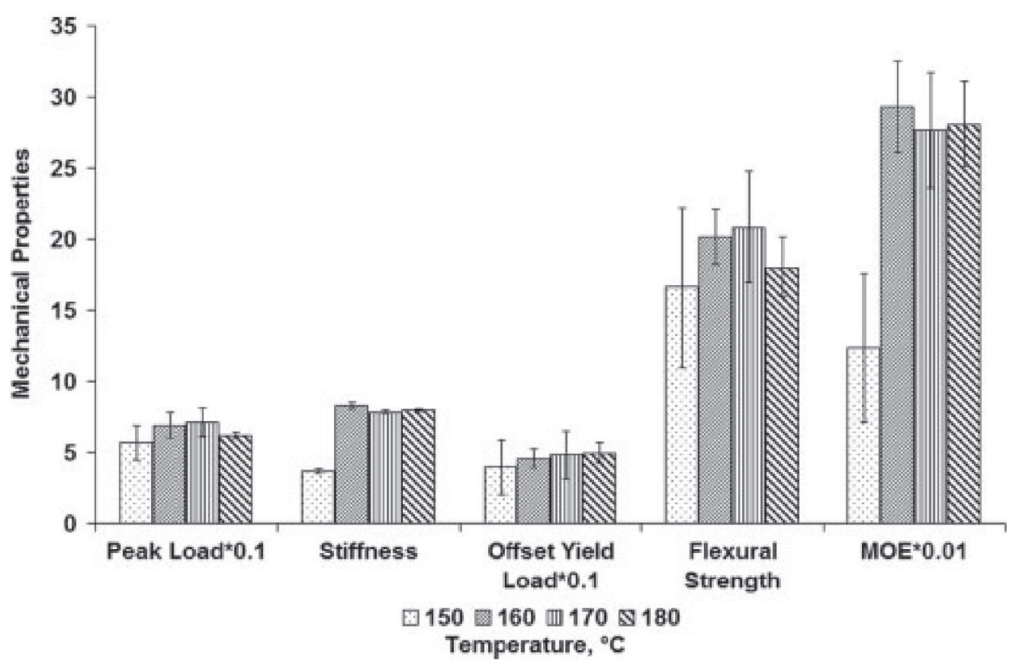

Figure 4. Effect of compression temperature on flexural properties of wheat gluten-jute composites. The composites were manufactured by compression molding for $15 \mathrm{~min}$ at various temperatures, controlling the thickness of the composite at $3.2 \mathrm{~mm}$ and density of $0.47 \mathrm{~g} \mathrm{~cm}{ }^{-3}$.

ties. However, excessive wheat gluten makes the composites brittle and reduces the flexural strength as seen for the $70 \%$ wheat gluten composites and indicated by the high stiffness. Previously, wheat gluten biocomposites reinforced with hydroethyl cellulose (HEC) used as filler provided the best properties at a HEC content of $31.8 \%$ when compression molded at $120^{\circ} \mathrm{C}$ for $5 \mathrm{~min}$. Similarly, hemp and wood fibers in ratios of $0,5,10$ and 20 wt\% were mixed with wheat gluten $(70 \%)$ plasticized with glycerol $(30 \%) .{ }^{23}$ It was reported that inclusion of the fibers improved the mechanical properties and water resistance of the composites..$^{23}$ It was also suggested that fiber addition did not affect the gluten crosslinking. ${ }^{23}$

\section{Effect of compression time on flexural properties}

The effect of increasing the compression time on the flexural properties of the composites is shown in Fig. 3. As can be seen, increasing the compression time increases the peak load, stiffness and flexural strength up to about $15 \mathrm{~min}$, but the flexural properties become poorer above a compression time of $15 \mathrm{~min}$. The stiffness and flexural strength show a considerable increase when the compression time is increased from 5 to $10 \mathrm{~min}$ and from 10 to 15 min. However, there is a considerable decrease in the peak load, stiffness and flexural strength when the compression time is increased from 15 to $20 \mathrm{~min}$. At short compression times, there is not enough time for the wheat gluten to be plasticized and able to bind the jute fibers together. In addition, water used as plasticizer in the composites is not completely removed at short compression times which may cause insufficient plasticization of wheat gluten and poor binding between the matrix and reinforcing materials. At long compression times (20 min), wheat gluten becomes dehydrated and brittle leading to inferior composite properties.

Effect of compression temperature on flexural properties Figure 4 shows the effect of compression temperature on the flexural properties of the composites. Increasing the compression temperature from 150 to $160^{\circ} \mathrm{C}$ considerably affects the stiffness and flexural strength but the peak load and offset yield load remain relatively unaffected. As with the compression time, lower temperatures do not provide enough plasticization and removal of water 
Table I. Effect of proportion of wheat gluten, compression time and temperature on the tensile strength and tensile modulus of composites

\begin{tabular}{|c|c|c|c|c|c|c|c|c|c|c|c|c|}
\hline $\begin{array}{l}\text { Composite } \\
\text { property }\end{array}$ & \multicolumn{4}{|c|}{ Wheat gluten/jute (wt\%) } & \multicolumn{4}{|c|}{ Temperature $\left({ }^{\circ} \mathrm{C}\right)$} & \multicolumn{4}{|c|}{ Time (min) } \\
\hline $\begin{array}{l}\text { Peak load } \\
\text { (MPa) }\end{array}$ & $52.9 \pm 4.9$ & $64.0 \pm 5.5$ & $68.6 \pm 9.1$ & $37.9 \pm 7.2$ & $65.2 \pm 5.3$ & $63.1 \pm 8.8$ & $68.6 \pm 9.1$ & $52.2 \pm 4.6$ & $69.9 \pm 4.7$ & $71.6 \pm 5.1$ & $68.6 \pm 9.1$ & $72.3 \pm 6.1$ \\
\hline $\begin{array}{l}\text { Modulus } \\
(\mathrm{GPa})\end{array}$ & $6.2 \pm 0.5$ & $6.5 \pm 0.9$ & $7.7 \pm 1.2$ & $4.6 \pm 0.4$ & $6.4 \pm 0.6$ & $6.2 \pm 0.6$ & $7.7 \pm 1.2$ & $6.0 \pm 0.4$ & $6.7 \pm 0.4$ & $6.3 \pm 0.6$ & $7.7 \pm 1.2$ & $7.2 \pm 0.5$ \\
\hline
\end{tabular}

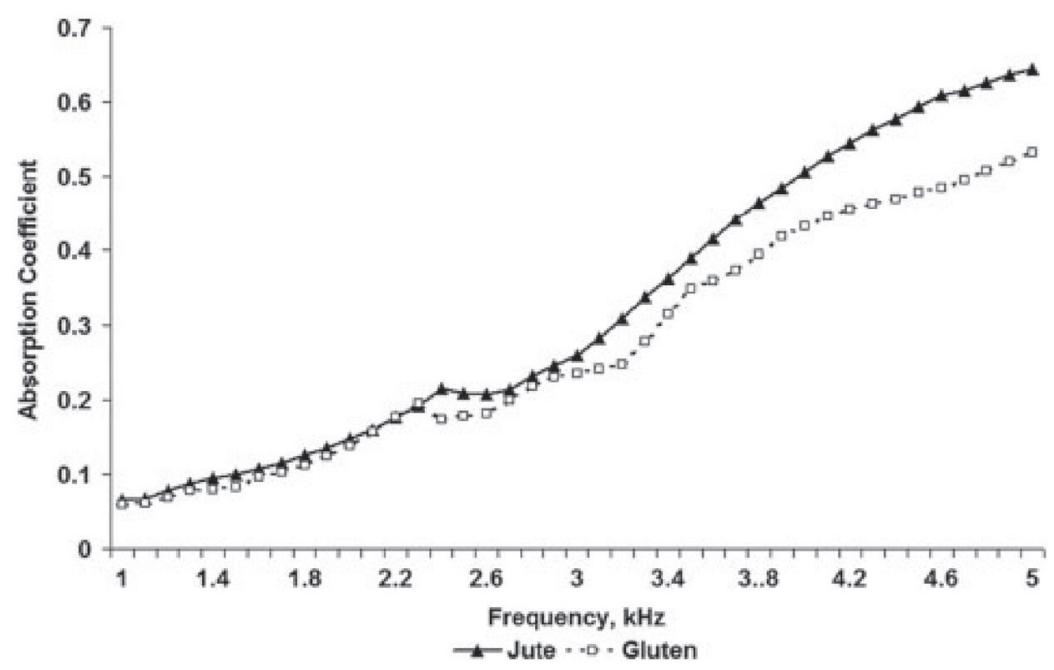

Figure 5. Sound absorption coefficient of wheat gluten-jute composites compared to PP-jute composites at various frequencies. The wheat gluten composites were made with a density of $1300 \mathrm{~g} \mathrm{~m}^{-2}$ using $60 \%$ wheat gluten by compression molding at $170{ }^{\circ} \mathrm{C}$ for $15 \mathrm{~min}$.

from the composites resulting in poor flexural strength. However, high temperature $\left(180^{\circ} \mathrm{C}\right)$ dehydrates the wheat gluten making it brittle and hence reducing the strength of the composites.

It has been reported that treating wheat gluten at high temperatures induces crosslinkages within the wheat protein and also results in the formation of intermolecular covalent bonds leading to an increase in tensile strength. ${ }^{20-22}$ The extent of crosslinkages and covalent bonds was reported to be dependent on the temperature and time of processing of the wheat gluten. At low temperatures, there was low protein unfolding and crosslinking. At high molding temperatures, the plasticized wheat gluten formed a homogenous network and provided good strength and extensibility. ${ }^{20}$ Previous studies on developing composites and films from plasticized wheat gluten have used compression temperatures from 65 to $130^{\circ} \mathrm{C}$, mostly between 120 and $130{ }^{\circ} \mathrm{C}$ and not higher than $130^{\circ} \mathrm{C} .{ }^{19-25} \mathrm{~A}$ higher temperature of $150-180^{\circ} \mathrm{C}$ was used in the present study for compression molding due to the presence of water equivalent to twice the weight of the wheat gluten and jute fibers used. When compression molded, most of the water escapes as steam from the wheat gluten and jute fibers from the sides of the composites press and considerable amounts of heat are consumed in the process. Therefore, higher temperatures are necessary to compression mold the water-plasticized wheat gluten.

\section{Effect of composite fabrication conditions on tensile properties}

Table I summarizes the tensile properties of the wheat glutenjute fiber composites at various composite-forming conditions. Increasing the proportion of wheat gluten from 30 to $50 \%$ and from
50 to $60 \%$ increases the tensile strength and modulus. Further increase in wheat gluten to $70 \%$ decreases the tensile strength by about $45 \%$ and the modulus by about $40 \%$ compared to the composites with $60 \%$ wheat gluten. Increasing the temperature from 150 to $170{ }^{\circ} \mathrm{C}$ does not affect the tensile strength but the composites made at $170{ }^{\circ} \mathrm{C}$ have higher modulus that those made at lower temperatures. Increasing the compression temperature from 170 to $180^{\circ} \mathrm{C}$ considerably decreases the strength and modulus. Unlike increasing the percentage of wheat gluten and compression temperature, increasing the compression time does not decrease the tensile strength or modulus. Composites made with a compression time from 5 to 20 min have similar tensile strength and modulus. The decreasing tensile strength and modulus with increasing wheat gluten concentration to $70 \%$ could be due to insufficient reinforcing fibers. Similarly, the poor properties of the composites at $180^{\circ} \mathrm{C}$ could be due to damage to the wheat gluten. The wheat gluten could have been degraded and become brittle at high temperatures as indicated by the flexural properties. Overall, a wheat gluten concentration of $60 \%$, compression temperature of $160{ }^{\circ} \mathrm{C}$ and compression time of 15 min provide composites with the best tensile strength and tensile modulus.

\section{Sound absorption}

The sound absorption coefficients of the wheat gluten and PP composites reinforced with jute fibers at various frequencies are shown in Fig. 5. As can be seen, the wheat gluten and PP composites have similar sound absorption from I to about $3 \mathrm{kHz}$. Above $3 \mathrm{kHz}$, the sound absorption of the jute composites is higher than that of the PP composites. This could be due to the differences in the densities between wheat gluten and PP. 
Table 2. Comparison of optimized flexural and tensile properties of wheat gluten-jute composites and PP-jute composites at two different humidities

\begin{tabular}{|c|c|c|c|c|c|}
\hline $\begin{array}{l}\text { Matrix } \\
\text { material }\end{array}$ & $\begin{array}{c}\text { Flexural } \\
\text { strength } \\
(\mathrm{MPa})\end{array}$ & $\begin{array}{l}\text { Stiffness } \\
\left(\mathrm{N} \mathrm{mm}^{-1}\right)\end{array}$ & $\begin{array}{c}\text { Modulus of } \\
\text { elasticity } \\
(\mathrm{MPa})\end{array}$ & $\begin{array}{c}\text { Tensile } \\
\text { strength } \\
(\mathrm{MPa})\end{array}$ & $\begin{array}{c}\text { Tensile } \\
\text { modulus } \\
(\mathrm{GPa})\end{array}$ \\
\hline \multicolumn{6}{|c|}{$21{ }^{\circ} \mathrm{C}, 65 \% \mathrm{RH}^{\mathrm{a}}$} \\
\hline Gluten & $20.2 \pm 2.0$ & $8.3 \pm 2.4$ & $2928 \pm 259$ & $68.6 \pm 9.1$ & $7.7 \pm 1.2$ \\
\hline PP & $10.6 \pm 1.1$ & $1.4 \pm 0.2$ & $500 \pm 79$ & $35.2 \pm 5.5$ & $3.2 \pm 0.6$ \\
\hline \multicolumn{6}{|c|}{$21^{\circ} \mathrm{C}, 90 \% \mathrm{RH}^{\mathrm{a}}$} \\
\hline Gluten & $10.4 \pm 2.2$ & $1.2 \pm 0.6$ & $434 \pm 77$ & $28.6 \pm 3.8$ & $3.7 \pm 0.6$ \\
\hline PP & $10.6 \pm 1.1$ & $1.4 \pm 0.3$ & $495 \pm 116$ & $31.3 \pm 8.1$ & $2.4 \pm 0.5$ \\
\hline
\end{tabular}

a. $\mathrm{RH}=$ relative humidity

\section{Comparison with PP-jute composites}

Table 2 provides a comparison of the optimized flexural and tensile properties of the wheat gluten composites and PP composites reinforced with jute fibers at two relative humidities. The wheat gluten composites were manufactured using $60 \%$ gluten at $170{ }^{\circ} \mathrm{C}$ for $15 \mathrm{~min}$. The PP composites were manufactured using $40 \%$ PP and $60 \%$ jute and compression molded at $190{ }^{\circ} \mathrm{C}$ for 90 s. As seen from Table 2, the wheat gluten composites have much higher flexural and tensile properties compared to the PP composites at $21{ }^{\circ} \mathrm{C}$ and $65 \%$ relative humidity. The flexural strength, tensile strength and modulus of the wheat gluten composites are approximately two times higher and the stiffness and MOE about six times higher than those of the PP composites. The better properties of the wheat gluten composites are most likely due to the better compatibility between wheat gluten and jute fibers than the hydrophobic PP and hydrophilic jute fibers.

However, the wheat gluten composites have considerably inferior properties at higher relative humidity $(90 \%)$ compared to their properties at $65 \%$ relative humidity. The flexural strength and tensile modulus of the wheat gluten composites decrease by about $50 \%$, tensile strength by about $60 \%$ and stiffness and MOE by about 7 times at $90 \%$ relative humidity compared to the respective properties at $65 \%$ relative humidity. The PP composites do not show any considerable deterioration in the flexural properties at $90 \%$ relative humidity mainly because PP does not absorb large amounts of moisture in contrast to wheat gluten and jute fibers. Although the wheat gluten composites have inferior properties at $90 \%$ relative humidity, the flexural and tensile properties of the wheat gluten composites at $90 \%$ relative humidity are very similar to those of the PP composites. As seen from Table 2, the wheat gluten composites have very similar flexural properties and slightly higher tensile modulus than the PP composites at $90 \%$ relative humidity. Wheat gluten and jute absorb moisture and become soft at high humidity leading to a decrease in stiffness and MOE. The comparable flexural and tensile properties of the wheat gluten composites and PP composites at high humidities indicate that the wheat gluten composites would be useful for various applications.

\section{Conclusions}

The research reported showed that wheat gluten composites developed using water as a plasticizer had much better flexural and tensile properties than composites made using PP as the matrix. Water-plasticized wheat gluten had a broad melting peak between $\mathrm{I} I 0$ and $170^{\circ} \mathrm{C}$ with a melting enthalpy of $1.3 \mathrm{~kJ} \mathrm{~g}^{-1}$. It was found that composites with $60 \%$ wheat gluten $/ 40 \%$ jute and compression molded at $160{ }^{\circ} \mathrm{C}$ for $15 \mathrm{~min}$ had optimum properties. At the optimized conditions, the wheat gluten composites had double the flexural strength $(20 \mathrm{MPa})$, tensile strength $(69 \mathrm{MPa})$ and modulus (7.7 GPa) compared to the PP composites reinforced with jute fibers. The wheat gluten composites had considerably poorer flexural and tensile properties at $90 \%$ humidity compared to the properties at $65 \%$ humidity but similar to those of the PP composites.

Wheat gluten is an inexpensive byproduct that has a selling price less than those of the common synthetic polymers such as polyethylene and polystyrene used for thermoplastic applications. Eliminating the need for plasticizers such as glycerol or chemical modifications to make wheat gluten thermoplastic will reduce the cost and make wheat gluten thermoplastics competitive with synthetic polymer-based thermoplastics. In addition, wheat gluten thermoplastics developed using water as a plasticizer will be completely biodegradable and environmentally friendly. Water-plasticized wheat gluten has the potential to be used for developing various thermoplastic products.

Acknowledgments - The authors thank the Nebraska Wheat Board, the Agricultural Research Division at the University of Nebraska-Lincoln, USDA Hatch Act and Multistate Research Project SI026 for their financial support to complete this work. Archer Daniels Midlands Company is also acknowledged for providing the wheat gluten.

\section{References}

I Huang A and Netravali A, Compos Sci Technol 69:I009-10I5 (2009).

2 Mohanty AK, Misra M and Hinrichsen G, Macromol Mater Eng 276/277: I24 (2000).

3 El-Wakil NA, Abou-Zeid RE, Fahmy Y and Mohamed AY, J Appl Polym Sci I 06:3592-3599 (2007).

4 Chabba S and Netravali AN, JMater Sci 40:6263-6273 (2005).

5 Liu Z, Erhan SZ, Akin DE and Barton FE, J Agric Food Chem 54:2134-2137 (2006).

6 Zou Y, Huda S and Yang Y, Bioresour Technol I 0 I:2026-2033 (2010).

7 Huda S and Yang Y, Compos Sci Technol 68:790-798 (2008).

8 Huda S and Yang Y, MacromolMater Eng 293:235-243 (2008).

9 Huda S and Yang Y, J PolymEnviron I 7:131-142 (2009).

10 Huda S and Yang Y, Ind Crop Prod 30:17-23 (2009).

I I Duigou AL, Davies P and Baley C, Compos Sci Technol 70:23 I-239 (20I0).

I2 Lee MW,Han SOandSeo YB,ComposSciTechnol 68:I266-I272(2008).

I3 Wan YZ, LuoH, He F, LiangH, Huang Y and Li XL, Compos Sci Technol 69:1212-1217 (2009)

I4 Day L, Augustin MA, Batey IL and Wrigley CW, Trends Food Sci Technol I 7:82-90 (2006).

I5 Reddy N and Yang Y, Green Chem 7:190-195 (2005).

I6 Reddy N and Yang Y, Bioresour Technol I 00:3593-3598 (2009).

I 7 Reddy N and Yang Y, Bioresour Technol 1 00:3563-3569 (2009).

I8 Lee S andWang S, Composites A 37:80-9I (2006).

19 Song Y, Zheng Q and Liu C, Ind Crop Prod 28:56-62 (2008).

20 Sun S, Song Y and Zheng Q, Food Hydrocoll 22: I006-I0I3 (2008).

2 I PommetM, Redl A, Guilbert S and Morel M, J Agric Food Chem 53:39433949 (2005).

22 PommetM, Redl A, Guilbert S and Morel M, J Cereal Sci 42:8I-9I (2005).

23 Kunanopparat T, Menut P, Morel MH and Guilbert S, Composites A 39:777785 (2008).

24 Wretfors C, Cho S, HedenqvistMS, Marttila S, Nimmermark S and Johansson E, J PolymEnviron I 7:259-266 (2009).

25 Gällstedt M, Mattozzi A, Johansson E and Hedenqvist MS, Biomacromolecules 5:2020-2028 (2004).

26 Kim S, Bioresour Technol 99:2032-2036 (2008).

27 Leon A, Rosell CM and Barber B, Eur Food Res Technol 2 I 7: I3-16 (2003). 